\title{
PENGEMBANGAN KECERDASAN MAJEMUK (MULTIPLE INTELLIGENCES) DI MADRASAH
}

\author{
Zainal Abidin \\ Institut Agama Islam Negeri Metro \\ Jl. Ki Hajar Dewantara 15A Iring Mulyo Kota Metro \\ zainaltob@yahoo.co.id
}

\begin{abstract}
Abtract
Intelligence isn't black and white there are some aspects of human intelligences not just one only. At least, there are nine types of human intelligence called multiple intelligences. Nine types of intelligence is very affecting the success of a person in the competition of life. This paper will discuss the strategy of developing multiple intelligences in madrasah as one of the Islamic educational institutions. In the reality of educational practice in madrasah shows that the priciple of multiple intelligence has long been alpied througth several materials integrated with each other. The development of potential learners in madrasah has long been developed in the several aspect of emotional, intellctual, spiritual, social and individuality intelligence in accordance with the principles of Islamic teaching.
\end{abstract}

Key word: Multiple Intelligences, Madrasah, primary education

\begin{abstract}
Abstrak
Kecerdasan tidak hitam putih ada beberapa aspek kecerdasan manusia bukan hanya satu saja. Paling tidak, ada sembilan jenis kecerdasan manusia yang disebut multiple intelligences. Sembilan jenis kecerdasan sangat mempengaruhi keberhasilan seseorang dalam persaingan hidup. Makalah ini akan membahas strategi pengembangan kecerdasan majemuk di madrasah sebagai salah satu institusi pendidikan Islam. Kenyataannya praktik pendidikan di madrasah menunjukkan bahwa prinsip kecerdasan ganda telah lama menelan beberapa bahan yang saling terintegrasi satu sama lain. Perkembangan pelajar potensial di madrasah telah lama berkembang dalam beberapa aspek kecerdasan emosional, intelektual, spiritual, sosial dan individualitas sesuai dengan prinsip pengajaran Islam.

Kata kunci: Multiple Intelligences, madrasah, pendidikan dasar
\end{abstract}

\section{Pendahuluan}

Konsep dan teori kecerdasan manusia berkembang dengan pesat, seiring dengan berbagai penelitian dalam disiplin ilmu psikologi modern. Sejak psikologi diakui sebagai disiplin ilmu yang otonom, pada akhir abad ke 19, pengembangan konsep kecerdasan terus mengalami penemuanpenemuan baru di bidang teori kecerdasan intelektual manusia. Temuan beberapa teori dan ditindaklanjuti dengan serangkaian tes kecerdasan manusia telah melahirkan beberapa formula antara lain tes IQ yang dikembangkan oleh Alfret Binet (1857- 1911), 
seorang ahli psikologi dari Perancis, tahun 1905. Kemudian rumus Binet disempurnakan lagi oleh William Stern seorang psikolog Jerman pada tahun 1912.

Model tes IQ terus berkembang melintasi benua, hingga ke Amerika dan terus mengalami penyempurnaan standar tes, seperti yang dilakukan oleh Lewis Terman, pada tahun 1916. Beberapa nama besar juga telah melakukan revisi sejak pertama kali tes IQ dilakukan oleh Binet, antara lain adalah David Wechsler (1896-1981) yang berhasil menggeser dominasi model tes Binet. Kalau hasil tes psikologi Binet hanya menghasilkan satu nilai, maka hasil tes Wechsler menghasilkan nilai yang lebih lengkap. Di antaranya tingkat kecepatan persepsi, penalaran, pemahaman verbal, asosiasi memori dan sebagainya. Sejak tahun 1960 Wechler telah menggusur model tes Binet dan berhasil mendominasi tes IQ di Amerika dan menjadi standar tes yang lebih populer. ${ }^{1}$

Terakhir revisi tes IQ dilakukan lagi oleh seorang psikolog dari Amerika, Howard Gadner dari Harvard University, pada tahun 1983, dan mulai diperkenalkan terobosan baru di bidang tes IQ dengan memasukkan konsep mengenai tujuh bahkan delapan kecerdasan berbeda yang disebut dengan kecerdasan ganda atau kecerdasan majemuk. $^{2}$ Walupun demikian tes IQ hingga sekarang tetap digunakan sebagai standar untuk mengukur tingkat

1 Mengenal IQ-Intelligence Quotient. Sains me www. Google.co.id.

${ }^{2}$ Campbel, L et,al. Teaching and Learning Throught Multiple Intelligences, (Massachusetts: Allyn and Bacon, 1996), h. 78. kecerdasan manusia dan rujukan standar yang digunakan bagi tes IQ di era modern. Gradasi tingkat kecerdasan manusia dibagi dalam beberapa stratum atau kategori, antara lain ediot, embicil, normal dan genius. $^{3}$

Pola pengembangan kecerdasan manusia ternyata terus berkembang dengan beberapa konsep baru, bahwa kesempurnaan kecerdasan manusia bukan hanya bisa dilihat dari prestasi tes IQ nya saja, tetapi lebih dari itu, kecerdasan seseorang bisa dilihat dari berbagai aspek kecerdasan lainnya antara lain kecerdasan emosional, kecerdasan spiritual, kecerdasan sosial dan sebagainya. Karena secara realitas empirik, konsep kecerdasan yang didasarkan pada otak manusia saja, atau kecerdasan intelektual saja tidak mampu secara efektif menyelesaikan berbagai problema yang ada dalam lingkup kehidupan manusia, tidak sedikit penyandang prediket manusia tercerdas secara intelektual, tetapi merasa tersisih dan terbuang atau gagal dalam persaingan hidup, bahkan ada beberapa kasus yang memutuskan untuk mengambil jalan pintas mengakhiri hidupnya.

Muculnya konsep baru mengenai kecerdasan majemuk tersebut dalam konteks ilmu psikologi dan pendidikan, didasari oleh beberapa alasan rasional dan realitas empiris yang mengindikasikan bahwa seseorang yang sukses dalam tes IQ dengan kategori jenius, atau orang yang ber-IQ jenius, ternyata gagal dalam pergaulan sosial

3 Dave Meier, The Accelerated Learning Handbook; A Creative Guide to designing and Delivering Faster, More Effective Training Program, (Massachusetts: Allyn and Bacon, 2000), h. 90. 
dan kompetesi global di dunia ini. ${ }^{4}$ Oleh karena itu kemudian muncul konsep kecerdasan ganda atau kecerdasan majemuk, yang bukan hanya menekankan kecerdasan intelektual, tetapi lebih luas lagi, mencakup kecerdasan emosional, spritual dan sosial, mungkin ada konsep kecerdasan lainnya.

\section{Sejarah Perkembangan Teori}

\section{Kecerdasan Majemuk}

Teori kecerdasan (Multiple Intelligence) atau ada yang menyebutnya sebagai teori "kecerdasan ganda" yang terkenal belakangan ini, untuk pertama kali dikemukakan oleh Howard Gadner dari Harvard Graduate School of Education and Psychology di Harvard University Amerika Serikat. Dalam bukunya Frames of Mind (1983), Gadner menyatakan bahwa pada dasarnya manusia mempunyai tujuh jenis kecerdasan, yaitu kecerdasan bahasa, matematis logis, spasial, kinestetis jasmani, musikal, interpersonal dan kecerdasan intrapersonal. Kemudian pada tahun 2000, Gadner dalam bukunya, Intelligence Reframed, menambahkan 2 lagi jenis kecerdasan yaitu kecerdasan naturalis dan kecerdasan eksistensialis. ${ }^{5}$ Jadi terdapat 9 jenis kecerdasan manusia yang disebut sebagai kecerdasan majemuk. Konsep kecerdasan majemuk ini mendapat perhatian utama manusia pada abad ke 20 dan mampu menggeser sedikit demi sedikit dominasi teori kecerdasan intelektual.

Menurut Gadner kecerdasan

${ }^{4}$ Budiningsih, Belajar dan Pembelajaran, (Jakarta: Rineka Cipta, 2005), h. 67.

5 Dalton, Creative Thinking and Cooperative Talk in Small Group, (Australia: Thomas Nelson, 1990), h. 89. manusia tidak bersifat tunggal, artinya kecerdasan manusia tidak bisa hanya diukur dari kecerdasan dalam menjawab materimateri dalam pembelajarn semata, namunkecerdasan manusia itu juga dinilai berdasarkan: (a) kemampuan untuk menyelesaikan masalah yang terjadi dalam kehidupan. (b) kemampuan menemukan persoalan-persoalan baru untuk diselesaikan atau dicari solusinya. (c) kemampuan untuk menciptakan sesuatu dan memberikan penghargaan dalam budaya seseorang. ${ }^{6}$

Sembilan kecerdasan tersebut dapat dijelaskan secara rinci. Pertama, kecerdasan bahasa (linguistik) berisi kemampuan untuk berpikir dengan kata-kata dan menggunakan bahasa untuk mengespresikan arti yang kompleks. Contoh orang yang mepunyai kecerdasan bahasa antara lain ialah pengarang, penyair, wartawan, pembicara, pembaca berita dan sebagainya. Kedua, kecerdasan matemati/logis, yaitu kemampuan yang memungkinkan seseorang terampil dalam hitungan atau kuantifikasi, mengemukakan proposisi dan hipotesis, melakukan operasi matematis yang kompleks. Orang dengan kategori ini, antara lain, ilmuwan, matematikawan, akuntan, insinyur,pemogram komputer dan lain-lain. Ketiga, kecerdasan spasial yaitu orang yang mempunyai kapasitas dalam berpikir secara tiga dimensi. Kecerdasan spasial memungkinkan individu dapat mempersepsikan gambar-gambar baik internal maupun eksternal dan mengartikan atau mengkomunikasikan informasi grafis.

${ }^{6}$ Howard Gadner, "Heteroglossia: A Global Perspective" Interdisciplinary Journal of Theory of Post Pedagogogical Studies, 1984 
Contohnya orang yang memiliki kecerdasan spasial ini antara lain adalah pelaut, pilot, pematung, pelukis dan arsitek. Keempat, kecerdasan kinestetik tubuh adalah kecerdasan yang memungkinkan seseorang yang memanipulasi obyek dan cakap melakukan aktifitas fisik. Contoh orang yang mempunyai kecerdasan kinestetis ini adalah para atlit, penari, ahli bedah, pengrajin dan sebagainya. Kelima, kecerdasan musikal adalah jenis kecerdasan dibuktikan dengan adanya rasa sensitif terhadap nada, irama musik, melodi atau yang berkaitan dengan musik. Contohnya antara lain komposer, konduktor, musisi, kritikus musik, pembuat instrumen dan orang yang sensitif terhadap unsur suara. Keenam, kecerdasan interpersonal, yaitu kapasitas yang dimiliki seseorang untuk dapat memahami dan dapat melakukan interaksi secara efektif dengan orang lain. Kecerdasan interpersonal akan dapat dilihat dari beberapa orang seperti guru yang sukses, pekerja sosial, aktor, politisi. Kecerdasan interpersonal dalam beberapa penelitian dainggapsebagai salah satu kunci sukses seseorang. Ketujuh, kecerdasan intrapersonal, yaitu kecerdasan yang dapat diperlihatkan dalam bentuk kemampuan dalam membangun persepsi yang akurat tentang diri sendiri dan menggunakan kemampuan tersebut dalam membuat rencana dan mengarahkan orang lain. ${ }^{7}$ Contohnya para manajer, direktur, pimpinan organisasi dan sebagainya.

${ }^{7}$ Howard Gadner, Reflection on Multiple Intelligences: Myths and Message, dalam Phi Delta Kappan, 1997.
Kedelapan kecerdasan naturalis, yaitu bentuk kecerdasan berupa kemampuan mengkategorikan spesies-flora dan fauna di lingkungannya. Contohnya adalah para pencinta alam, ahli botani dan sebagainya. ${ }^{8}$ Kesembilan, kecerdasan eksistensial, yaitu kecerdasan berupa kemampuan menjawab persoalan-persoalan eksistensi manusia atau sopan santun, atau memiliki spritual quotient, baik terhadap sesama, sopan serta pandai menjaga rahasia.

Sembilan jenis kecerdasan majemuk tersebut mengindikasikan betapa kaya potensi yang dimiliki oleh manusia, sebagai salah satu makhluk Allah yang paling sempurna, sebagaimana yang diinformasikan dalam al-Qur'an. Kelebihan manusia juga tentunya diikuti oleh beberapa kelemahan. Potensi kecerdasan majemuk yang dikemukakan oleh Gadner, mungkin masih belum seluruhnya tereksplorasi dari berbagai potensi manusia yang terpendam. Kecerdasan manusia baik berupa kecerdasan individu maupun kecerdasan kolektif juga menunjukkan bahwa manusia menyimpan potensi yang luar biasa positifnya bila dikembangkan secara benar, misalnya dengan menggunakan pendekatan agama dan sebagainya. Tetapi sebaliknya jika potensi besar tersebut dikembangkan dengan pendekatan yang salah, misalnya dengan pendekatan sekuler, maka hasilnya juga akan menimbulkan mala petaka yang luar biasa bagi kehidupan manusia.

Pengembangan kecerdasan majemuk (multiple intelligence) yang sekarang sedang populer seharusnya, senantiasa diwarnai oleh nilai-nilai keagamaan, terutama

\footnotetext{
8 Teori Kecerdasan Ganda dan Penerapannya dalam Kegiatan Pembelajaran, dalam Fadilbae Weblogs
} 
pendekatan agama Islam, supaya semangat yang dikandung dalam konsep kecerdasan majemuk tersebut tidak menjadi sesuatu yang kehilangan makna, akibat terlalu dipengaruhi oleh filsafat sekuleristik. Bukan berarti kita curiga dengan konsep-konsep yang bagus mengenai kecerdasan majemuk yang berasal dari Barat, tetapi paling tidak upaya untuk memberikan sentuhan agama sangat penting dilakukan untuk memberi spirit keagamaan sebagai salah satu kebutuhan fitrah yang dimiliki oleh manusia. Dengan begitu kecerdasan majemuk akan lebih bermakna karena memperhatikan kebutuhaan asasi manusia sebagai makhluk yang bertuhan dan beragama.

Oleh sebab itu tugas intelektual muslim, terutama yang konsens dengan masalah psikologi kepribadian maupun bidang bidang pendidikan pada umunya hendaknya mampu memberikan kontribusi bagi pengembangan teori kecerdasan majemuk tersebut/agar bisa dikembangkan dalam konteks aplikatif, dengan sentuhan nilai-nilai ajaran agama Islam

Konsep kecerdasan majemuk mengalami pertumbuhan yang luas, tetapi harus diakui bahwa kemunculan konsep baru tersebut tampaknya belum mampu sepenuhnya menggeser konsep dan teori kecerdasan IQ. Hal ini bisa dilihat hingga saat ini ukuran kecerdasan berdasarkan teori IQ lebih banyak digunakan, karena dapat dilakukan pengukuran berdasarkan rumus kuantitaif. Sementara konsep dan teori kecerdasan majemuk hingga sekarang belum adap patokan yang dapat digunakan untuk mengukurnya. Mungkin dimasa depan akan ditemukan formulasi yang akurat dalam menentukan tingkat kecerdasan majemuk tersebut. Meskipun sekarang sudah ditemukan beberapa indikator kecerdasan majemuk tersebut yang ternyata lebih kompleks, dan pasti akan terus berkembang. Hal ini disebabkan karena obyek material dari ilmu tersebut adalah manusia yang mempunyai keunikan dan sisi-sisi misterius untuk diteliti dari dulu hingga kini, mungkin sampai kiamat nanti.

Konsep dan teori kecerdasan majemuk ini juga kemudian menstimulir lahirnya konsep-konsep kecerdasan lainnya yaitu kecerdasan emosional, spritual dan kecerdasan emosional yang belakangan juga mengalami perkembangan yang signifikan. Di samping itu, konsep-konsep kecerdasan tersebut juga telah melahirkan beberapa stategi pembelajaran yang beragam pula misalnya pembelajaran aktif, pembelajaran kolaboratif, pembelajaran kooperatif dan lain-lainnya.

Masalah utamanya apakah konsep atau teori kecerdasan majemuk ini bisa dikembangkan dalam pembelajaran Islam yang dilaksanakan di madrasah atau tidak. Karena secara realitas prinsip dan jenis kecersadan majemuk tersebut sebagian besar sesuai dengan kenyataan empirik dalam konteks praktek pembelajaran di madrasah. Secara faktual juga kecerdasan majemuk juga berkorelasi dengan pengalaman pembelajaran dimadrasah atau lembaga pendidikan Islam lainnya misalnya di pesantren. Walaupun begitu sseuai dengan stessing tulisan ini hanya akan membedah pengembangan kecerdasan majemuk di madrasah saja dilihat dari perspektif kurikulum dan materi atau bahan ajar yang 
diberikan pada peserta didik di madrasah.

\section{Strategi Pengembangan Multiple Intelegences di Madrasah}

Implementasi kecerdasan majemuk di dalam aktivitas pembelajaran memerlukan dukungan komponenkomponen, antara lain orang tua murid, guru, kurikulum dan fasilitas serta sistem penilaian. Namun dalam konteks pelaksanaan pembelajaran di madrasah tampaknya pendidiklah yang paling berperan dalam proses ini, dengan jalan mengetahui kecerdasan setiap individu peserta didik, kemudian ditunjang oleh kemampuan mengajar yang baik. Amstrong (2004) mengemukakan proporsi waktu yang dapat digunakan oleh guru dalam mengimplementasikan teori kecerdasan ganda yaitu dengan komposisi $30 \%$ pembelajaran langsung, $40 \%$ belajar kooperatif dan 30\% belajar independent. Dalam pengembangan kecerdasan majemuk di tingkat dasar perlu diperhatikan beberapa hal yang sangat urgen berkaitan dengan tingkat perkembangan fisik, psikis dan emosional anak. Pendidik dalam hal ini hendaknya memahami hal itu, sebab peserta didik mempunyai karakter yang berbeda-beda antara satu dengan lainnya. ${ }^{10}$

Sebenarnya dalam teori dan praktek pendidikan Islam, konsep kecerdasan mejemuk merupakan konsep yang sudah lama ada dan berkembang dikalangan kaum muslimin, karena terdapatnya integrasi praktek keagamaan

9 Amstrong, Sekolah Para Juara : Menerapkan Multiple Intellegences di Dunia Pendidikan, (Bandung: Kaifa, 2002), h. 23.

${ }^{10}$ Robert Slavin, Educational Psychology, (USA: Harvard University Press, 2000), h. 68. dengan dunia pendidikan. Konsep kecerdasan majemuk (Multiple Intelligence), menjadi dasar dalam praktek pendidikan Islam, karena merujuk pada semangat sumber utama agama Islam yaitu al-Qur'an dan al-Hadits. Kedua sumber primer dan sekunder tersebut dalam konteks kajian Islam menjadi landasan prinsipil yang mendasari dan mewarnai kajian pendidikan Islam yang sangat kaya. Konsep atau teori kecerdasan majemuk telah dikembangkan oleh para ulama sejak lama, dengan cara menekankan pentingnya keseimbangan dalam muatan kurikulum pendidikan Islam, yakni adanya pengembangan kecerdasan intelektual (aqliyah), kecerdasan psikis emosional (batiniyah), kecerdasan sosial (ijtimaiyah), kecerdasan kinestetis/ fisik (jismiyah), kecerdasan etis (akhlaqiyah), kecerdasan spritual/jiwa (ruhiyyah) dan lain sebagainya. Para ulama memaknai kecerdasan dengan komprehensif meliputi seluruh potensi dan dimensi yang dimiliki oleh manusia.

Dalam prakteknya pengembangan kecerdasan majemuk di madrasah dapat dilakukan oleh pendidik dengan menggabungkan teori-teori kecerdasan majemuk yang muncul dizaman kontemporer ini dengan pemikiranpemikiran ulama Islam sebagai warisan yang sangat berharga dalam pengembangan karakter peserta didik yang dijiwai oleh nilai-nilai keislaman dan nilai-nilai kemanusiaan. Maka dari itu, tugas pendidik sangat penting untuk memahami konsep kecerdasan majemuk dan bagaimana mengaplikasikannya dalam dunia pendidikan terutama di lembaga pendidikan Islam yakni madrasah, yang jumlahnya cukup banyak di Indonesia. 
Madrasah sebagai lembaga pendidikan yang sudah cukup lama ada masih sering dipandang sebagai lembaga pendidikan kelas dua, karena keberadaannya yang dianggap sebagai bagian dari lembaga tradisional pesatren yang beralih status menjadi lembaga formal yang kemudian berubah menjadi madrasah. Dengan kata lain madrasah merupakan bentuk metamorfosis pesantren pada era modern. Padahal pandangan ini salah, karena kalau dilacak dalam perspektif sejarah pendidikan Islam, eksistensi madrasah secara historis telah ada pada era Dinasti Abasiyah, dan merupakan lembaga pendidikan yang bergengsi karena mengajarkan berbagai ilmu yang waktu itu dianggap sebagai reoresentasi pendidikan tinggi dalam Islam. ${ }^{11}$ Dalam perkembangan selajutnya khususnya di dalam perspektif sejarah pendidikan Islam di Indonesia, madrasah dikategorikan sebagai lembaga pendidikan dasar dan menengah, sedangkan lembaga pendidikan tingginya menggunakan istilah "al-Jami'ah", atau setingkat institut dan universitas.

Keberadaan madrasah di Indonesia mempunyai sejarah dengan keberadaan pendidikan umat Islam di Indonesia, di samping pesantren dan sekolah. Madrasah menempati posisi strategis dan berkontribusi bagi kemajuan umat Islam dalam kompetisi Sumber daya Manusia. Seiring dengan dinamika sosial dan budaya, banyak alumni madrasah yang muncul menjadi tokoh-tokoh penting dalam berbagai bidang, berperan dalam pengembangan pendidikan khususnya

${ }^{11}$ Lihat Charles M. Stanton, Pendidikan Tinggi dalam Islam, (Jakarta: Logos, 1999), h’. 145. pendidikan Islam di Indonesia. Peranan madrasah cukup sentral sebagai lembaga yang menjadi ujung tombak pendidikan Islam, dia adalah benteng ketiga setelah pesantren dan masjid sebagai tempat pelestarian ajaran Islam kepada generasi selanjutnya.

Pengembangan kecerdasan majemuk di madrasah tampaknya sudah menjadi sebuah keniscayaan pada era modern. Meskipun sebenarnya dalam prakteknya kecerdasan majemuk bukan sesuatu yang asing lagi bagi pelaksanaan pembelajaran di madrasah, karena pendekatan pembelajaran dengan orientasi pengembangan kecerdasan tersébut sudah lama digunakan, walaupun tidak menggunakan istilah multiple intelligences dengan jalan mengandalkan kurikulum pendidikan berdasarkan nilainilai ajaran agama Islam, yang menganjurkan keseimbangan kompetensi. Guru sebagai ujung tombak pelaksanaan pembelajaran sepenuhnya harus memahami pentingnya kesadaran majemuk bagi peserta didik, dikarenakan kecerdasan itu akan menjadi bekal bagi kesuksesannya menghadapi tantangan masa depan, yang menuntuk kualitas dan kemampuan bersaing dengan keterampilan yang unggul berupa kekuatan spritual, teknis, relasi sosial, skill, atitude dan akhlak yang baik.

Sembilan jenis kecerdasan dalam konsep multiple intelligences sedapat mungkin secara maksimal diterapkan dengan prinsip-prinsip yang telah dikembangkan oleh beberapa ahli psikologi perkembangan. Prinsip-psinsip kecerdasan majemuk dapat diterapkan dengan berbagai metode pengajaran yang ada, dan memperhatikan dengan seksama terhadap 
minat dan bakat peserta didik. ${ }^{12}$ Sesuai dengan karakteristik pendidikan di madrasah yang mempunyai kurikulum bermuatan agama yang lebih besar, dan ditunjang oleh guru-guru mata pelajaran agama yang lebih profesional, dengan kemempuan mengajar bervariasi sesuai dengan kompetensi berdasarkan latar belakang pendidikannya. Beberapa mata pelajaran rumpun keagamaan secara signifikan sangat mendukung upaya pengembangan kecerdasan majemuk, yang meliputi sembilan kecerdasan yang diperoleh dalam proses pembelajaran di madrasah.

Sembilan kecerdasan dalam muliple intelligences itu antara lain; Pertama, kecerdasan lingusitik, dikembangkan melalui pembelajaran yang berbasis bahasa dalam rumpun mata pelajaran agama tentunya bisa diperoleh peserta didik dalam pelajaran bahasa Arab, sebagai bahasa kunci untuk memahamai pesan-pesan al-Qur'an dan al-Hadits. Melalui pembelajaran bahasa Arab anak juga mengetahui tentang kaidah-kaidah yang benar dalam gramatika bahasa Arab, sekaligus yang terpenting dari adalah peserta didik diharapkan mampu berhasa Arab baik secara lisan maupun tulisan. Kecerdasan linguistik di madsarah juga bisa didapatkan oleh peserta didik dari mata pelajaran lainnya yang berkorelasi dengan aspek pengembangan kecerdasan linguistik tersebut, misalnya dari pelajaran bahasa Inggris termasuk bahasa Indonesia. Dengan demikian inti dari

${ }^{12}$ Howard Gadner, "A Reply to Perry D. Klein's Multiplying the Problems of Intelligence by Eight", dalam Canadian Journal of Education, 1999. tujuan kecerdasan bahasa (lingusitik) yang berisi kemampuan untuk berpikir dengan kata-kata dan menggunakan bahasa untuk mengespresikan arti yang kompleks, dapat diperoleh peerta didik dengan baik. Sekaligus mengindikasikan bahwa isi materi pembelajaran bahasa di madrasah lebih unggul karena diajarkan tiga macam pelajaran bahasa sekaligus.

Kedua, kecerdasan matematis-logis yang berorientasi pada pengembangan kemampuan peserta didik berupa keterampilan dalam hitungan atau kuantifikasi, mengemukakan proposisi dan hipotesis, melakukan operasi matematis yang kompleks. Beberapa mata pelajaran yang mengembakan kecerdasan matematis ini disamping pelajaran matematika, fisika, kimia, dan sebagainya. Secara realitas di beberapa madrasah baik madrasah negeri maupun madrasah program khusus, atau sekarang dikenal dengan sebutan madrasah model, para peserta didik juga diajarkan beberapa disiplin ilmu yang mendukungnya, antara lain ilmu faraid, ilmu falak dan lain sebagainya. Sekali lagi kurikulum madrasah sesungguhnya lebih kuat misi pengembangan kecerdasan matematisnya, karena dalam prakteknya mata pelajaran yang bersifat eksakta sangat banyak diajarkan. Bahkan dalam beberapa madrasah di samping mata pelajaran matematika, juga diajarkan ilmu mantiq (logika) yang mengajarkan bagaimana berpikir dengan benar, karena antara matematika dan logika termasuk ilmu yang paling tua dalam sejarah sains yang berinduk pada filsafat.

Ketiga, kecerdasan spasial jenis kecerdasan ini memungkinkan seseorang 
berkemampuan memahami gambar secara tiga dimensi atau dengan kata lain membentuk orang yang mempunyai kapasitas dalam berpikir secara tiga dimensi. Kecerdasan spasial memungkinkan individu dapat mempersepsikan gambar-gambar baik internal maupun eksternal dan mengartikan atau mengkomunikasikan informasi grafis. Pembelajaran pendidikan agama Islam di madrasah diajarkan sejak usia dini, peserta didik diperkenalkan juga nilai-nilai estetika (seni) dalam pembelajaran. Di samping pembelajaran agama mereka juga diberikan beberapa pemahaman dan keterampilan untuk mampu melakukan kegiatan-kegiatan berupa kesenian yang bertujuan mengembangkan potensi estetik peserta didik, misalnya mata pelajaran keterampilan dan seni yang diajarkan sejak tingkat dasar, peserta didik diberikan tugas oleh gurunya untuk membuat lukisan dan sebagainya mulai dari lukisan dua dimensi hingga lukiran atau gambar tiga dimensi. Seiring dengan kemajuan teknologi mereka juga mulai diberikan materi teknologi digital grafis berupa gambar tiga dimensi untuk memjembatani pengembangan minat dan bakat masing-masing peserta didik.

$\begin{array}{lcr}\text { Keempat, } & \text { kecerdasan } & \text { kinestetik } \\ \text { tubuh adalah } & \text { kecerdasan } & \text { yang } \\ \text { memungkinkan } & \text { seseorang } & \text { yang } \\ \text { memanipulasi obyek dan } & \text { cakap } \\ \text { melakukan aktifitas fisik. Kecerdasan } \\ \text { kinestetik, pembelajaran di madrasah } \\ \text { secara realitas mengedepankan proses } \\ \text { pembelajaran praktek di samping } \\ \text { tentunya pembelajaran yang berbasis teori }\end{array}$

keilmuan. Dalam prakteknya kecerdasan kinestetis dapat dikembangkan melalui pembelajaran olah raga kesehatan atau pendidikan jasmani yang berusaha mengambangkan motorik siswa sehingga aktif dan sehat. Pengembangan kecerdasan kinestetik juga bisa dikembangkan melalui pembelajaran yang membutuhkan praktek misalnya pembelajaran fiqih, yang mengajari gerakan-gerakan yang benar dalam shalat dan lain sebagainya., palajaran ilmu faraidl, ilmu falak dan sebagaianya.

Kelima, kecerdasan musikal adalah jenis kecerdasan dibuktikan dengan adanya rasa sensitif terhadap nada, irama musik, melodi atau yang berkaitan dengan musik. Kecerdasan musikal dalam pembelajaran agama Islam di madrasah dapat dikembangkan dengan memberikan pelajaran seni suara atau seni musik tradissional Islam, dalam rangka pengembangan minat dan bakat peserta didik. Seni baca al-Qur'an yang menekankan keindahan suara (qira'at), sekaligus penekanan keharusan bacaan yang benar sesuai qaidah-qaidah dan hukum bacaan sesuai dengan ilmu tajwid (tartil). Sedangkan pengembangan aspek seni suara yang diiringi oleh musik bisa dikembangkan melalui seni rebanah, hadrah, qasidah dan sebagainya yang bernuansa religi. Secara realitas banyak lagu-lagu yang bernuansa religi sangat diterima oleh masyarakat, terutama di Indonesia yang mayoritas beragama Islam.

Keenam, kecerdasan interpersonal, yaitu kapasitas yang dimiliki seseorang untuk dapat memahami dan dapat melakukan interaksi secara efektif dengan orang lain. Pengembangan kecerdasan interpersonal ditekankan diberikan pada 
peserta didik karena ini merupakan kunci kesuksesannya, berupa pembelajaran yang menekankan relasi sosial dan relasi dengan lingkungan masyarakat di mana saja mereka nanti bekerja dan berperan dalam pergaulan sosial. Pembelajaran yang berdimensi pengembangan kecerdasan interpersonal, didapatkan peserta didik dari jenis pembelajaran akhlak yang bertujuan membentuk kepribadian mulia peserta didik sesuai dengan etika Islam (akhlak al-karimah). Di samping itu, berupa kegiatan-kegiatan yang menekankan siraram rohani yang membentuk kepribadian muslim yang sempurna. Dalam kaitan ini sudah menjadi kewajiban guru agama secara keseluruhan membentuk kepribadian sesuai dengan nilai-nilai keislaman.

Ketujuh,

kecerdasan intrapersonal, yaitu kecerdasan yang dapat diperlihatkan dalam bentuk kemampuan dalam membangun persepsi yang akurat tentang diri sendiri dan menggunakan kemampuan tersebut dalam membuat rencana dan mengarahkan orang lain. Kecerdasan intapersonal dapt dikembangkan melalui kegiatan-kegiatan ekstrakurikuler yang diadakan di madrasah yang beroerientasi bagi pengembangan kemampuan individual sekaligus kemampuan sosial peserta didik, diharapkan akan menjadi generasi masa depan yang tangguh melalui latihan-latihan kepemimpinan, keperwiraan, kewirausahaan dan lain sebagainya. Di antara kegiatan tersebut dapat dilakukan melalui latihan pramuka, pelatihan kepemimpinan dalam organisasai yang ada di madrasah, misalnya melalui kegiatan OSIS
(Organisasi Siswa Intra Sekolah), dan berbagai organisasi yang lainnya.

Kedelapan kecerdasan naturalis, yaitu bentuk kecerdasan berupa kemampuan mengkategorikan spesies-flora dan fauna di lingkungannya. Kecerdasan naturalis dapat dikembangkan melalu pemberian pelajaranpelajaran yang menekankan pesan-pesan ideal untuk senantiasa menjaga kelestarian lingkungan alam, serta larangan untuk mengekploitasi alam yang dapat merusak lingkungan. Hampir semua pembelajaran agama Islam di madrasah konten kurikulumnya berisi tentang larangan berbuat kerusakan di muka bumi, sebagaimana yang disebutkan dalam alQur'an, serta larangan berbuat berlebihlebihan, yang dapat merusak lingkungan alam. Disamping itu kecerdasan naturalis dapat dikembangkan secara kontinyu melali beberapa pembelajaran yang mengedepankan kesadaran akan pentingnya pemeliharaan alam, misalnya melalui pembelajaran geografi, ilmu pengetahuan alam dan sains, dan sebagainya.

Kesembilan, kecerdasan eksistensial, yaitu kecerdasan berupa kemampuan menjawab persoalan-persoalan eksistensi manusia atau, sopan santun, atau memiliki kecerdasan spiritual (spritual quotient). ${ }^{13}$ Kecerdasan ekstensial dapat dikembangkan dengan menekankan kemampuan spritual peserta didik, berupa kemampuan memahami hakekat dan jati dirinya sebagai manusia. Kecerdasan eksistensial ini juga berkaitan dengan dimensi bathiniyah setiap insan manusia yang harus diperhatikan,karena manusia secara realitas

${ }^{13}$ Lynn Gilman, The Theory of Multiple Intelligences, (USA : Indiana University, 2012), h. 325. 
terdiri dari dimensi fisik dan dimensi ruh atau jiwa (al-nafs/spirit). Disamping kebutuhan jasmaniyah yang membutuhkan perhatian untuk dikembangkan sesuai dengan kebutuhan fisik, dimensi jiwa atau ruh ini juga membutuhkan sentuhan dan perhatian, dengan pelibatan kebutuhan jiwa supaya tenang (al-naf al-mutmainnah) melalui kegiatan-kegiatan spritual keagamaan. Tujuannya supaya peserta didik sadar akan eksistensi dirinya sebagai makhluk. Dalam konteks ini pembelajaran di madrasah secara faktual mengajarkan halhal yang berkaitan dengan kebutuhan dimensi spiritual peserta didik, dan kesadaran akan arti penting kehidupan sesama manusia, toleransi, empati terhadap sesama dan sebagainya, melalui semua materi pembelajaran agama.

Dengan memperhatikan

kesembilan kecerdasan majemuk tersebut, tampaknya startegi pengembangannya dapat dilakukan secara komprehensif dengan menggali beberapa komponen kurikulum atau bahan pembelajaran yang diberikan kepada peserta didik oleh pendidik dal beragam mata pelajaran yang sangat bervarisi. Beragamnya mata pelajaran yang diajarkan tersebut mempunyai potensi yang sangat signifikan dalam pengembangan kecerdasan mejemuk dalam berbagai dimesni dan jenis-jenis kecerdasan majemuk tersebut. Disamping itu ternyata pengembangan kecerdasan majemuk di madrasah sebenarnya sudah lama dilakukan oleh pendidik untuk membentuk generasi yang berkualitas sesuai dengan ajaran Islam.

\section{Penutup}

Konsep kecerdasan majemuk (multiple intelligences) sebagai konsep atau teori yang lahir diakhir abad ke20, sebenarnya bertujuan untuk melihat kecerdasan manusi secar utuh bukan hanya kecerdasan intelektual semata.karena manusia mempunyai potensi yang sangat luas bukan hanya kemampuan pengetahuan saja tetapi juga potensi sosial, spiritual, emosional dan sebagainya, yang harus dikembangkan secara bersama-sama seiring dengan kecerdasan intelektual atau kecerdasan otak manusia. Dalam konteks ini pembelajaran dimadrasah secara realita memberikan kontribusi yang baik dalam pengembangan kecerdasan majemuk tersebut.

Madrasah sebagai salah satu lembaga pendidikan Islam mempunyai misi mulia mencetak manusia muslim yang berguna sempurna berkecerdasan dan berkembang secara intelektual, emosional, sosial, spritual, individual dan berakhlak mulia. Melalui pengembangan kecerdasan majemuk diharapkan mampu memberikan solusi bagi permasalahan sosial dan masa depan manusia yang lebih baik, khususnya bagi umat Islam dan manusia secara keseluruhan.

\section{Daftar Pustaka}

Amstrong, Sekolah Para Juara : Menerapkan Multiple Intelligences di Dunia Pendidikan, Bandung: Kaifa, 2002.

Budiningsih, Belajar dan Pembelajaran, Jakarta: Rineka Cipta, 2005.

Campbel, L et,al. Teaching and Learning 
Throught Multiple Intelligences, Massachusetts: Allyn and Bacon, 1999.

Charles M. Stanton, Pendidikan Tinggi dalam Islam, Jakarta: Logos, 1999.

Dalton, Creative Thinking and Cooperative Talk in Small Group, Australia: Thomas Nelson, 1990.

Dave Meier, The Accelerated Learning Handbook; A Creative Guide to Designing and Delivering Faster, More Effective Training Program, Massachusetts: Allyn and Bacon, 2000.

Howard Gadner, "Heteroglossia: A Global Perspective" Interdisciplinary Journal of Theory of Post pedagogogical Studies, 1984.
, Reflection on Multiple Intelligences: Myths and Message, dalam Phi Delta Kappan, 1997.

--------, “A Reply to Perry D. Klein's Multiplying the Problems of Intelligence by Eight", dalam Canadian Journal of Education, 1999

Lynn Gilman, The Theory of Multiple Intelligences, USA : Indiana University, 2012.

Mengenal IQ-Intelligence Quotient. Sains me www. Google.co.id.

Teori Kecerdasan Ganda dan Penerapannya dalam Kegiatan Pembelajaran, dalam Fadilbae Weblogs.

Robert Slavin, Educational Psychology, USA: Harvard University Press, 2000 